Proceedings of the 2011 Winter Simulation Conference

S. Jain, R.R. Creasey, J. Himmelspach, K.P. White, and M. Fu, eds.

\title{
EMPIRICAL MAKE-OR-BUY DECISION MAKING MODEL IN THE JAPANESE AUTOMOBILE INDUSTRY
}

\author{
Nguyen Dang Minh \\ University of Economics and Business, Vietnam National University, Hanoi \\ Xuan Thuy Str. 144 \\ Cau Giay Dist, Hanoi, VIETNAM
}

\begin{abstract}
The decision on whether Japanese automobile companies produce crucial components in-house or outsource them is complicated and time-consuming topic within the industry. In response to questions about the use of a make or buy model as part of a scientific decision making process for the issue, industrialists had the same answer that the final decision on make or buy has been made for the most part based on experiences and various discussions, and that no models were used. The main purpose of this paper is to propose a model for a make or buy decision from an empirical point of view. The model was developed as the Analytic Hierarchy Process (AHP) method in which the main criteria and sub-criteria were summarized from practical interviews with Japanese automobile industrialists. The proposed model also was applied in an actual project to confirm the feasibility of the model.
\end{abstract}

\section{INTRODUCTION}

In a global competitive environment, Japanese automobile manufacturing companies have always tried to find less expensive and superior way of either making their product or buying components from a capable supplier. In every project of production, the decision making on whether the company should produce crucial components in-house or out-source them is a serious discussion topic within the company. After conducting interviews with Japanese automobile manufacturers, it was realized that most companies base their decisions on transaction costs and product strategies from various discussions within the company; it also took time for reaching the final agreement because of many different point of views from each division of the company. However, in response to questions concerning the use of make or buy model as part of a scientific decision making process applied to the case for persuading manager and saving discussion time, industrialists who were interviewed for this study had the same answers that they do their job for the most part based on experiences. They were not applying any sufficient model for the make or buy decision-making process.

From an academic point of view, the topic concerning a make or buy approach has been discussed from many perspectives, such as transaction costs (Coase 1937; Williamson, 2005; Rindfleisch and Heide 1997; Masters and Grant 2002; David and Shin 2004), vertical integration (Masten, James, and Edward 1989; Langlois and Paul 1989; Ohanian 1994; Vannoni 2002), purchasing (Mike and Colin 2001) and operations research (Balakrishnan 1994). Several studies were conducted in supply chain management in identifying issues for the make or buy decision (Buchowicz 1991, Quinn and Hilner 1995).

The transaction cost theory of the firm introduced by Coase has become a standard framework for the study of institutional arrangements. Coase was the first to explain that the boundaries of the organization depend not only on the productive technology, but also on the costs of transacting business. Coase also recognized that it is not simply the price being charged in the market that needs to be taken into account, but all the costs of acquiring the commodity or process. Beside transaction cost, vertical integration is a 
central issue in the theory of the firm and industrial organization economics. There are several approaches in the literature on vertical integration. The first is the classical approach, which is based on technological and scale economies. The second approach on vertical integration is based on imperfect competition.

Regarding strategic issues, Probert (1997) discussed strategic make or buy decisions model that included several phases of analysis: initial business appraisal that addressed issues related to direction of the business and the customer preferences, and external/internal analysis. However, the model proposed by Probert was incomplete because it did not directly answer the original question of should the firm make the part or buy. Welch and Nayak (1992) discussed the strategic sourcing model that proposed a conceptual framework to support managers in accounting for strategic and technological factors. Venkatesan (1992) and Jennings (1997) introduced the strategic sourcing process, this process aimed to make the sourcing decision consistent with a strategy in highly engineered products. The model focused on: 1) those components that were critical product that the company was good at making; 2) outsource components where the supplier had a distinctive comparative advantage, greater scale, lower costs; and 3) structure performance incentives, using outsourcing as a means of generating employee commitment for improving manufacturing performance.

In addition, Porter (1985) proposed a make or buy model based on the conceptual model of the value chain that companies focus their own production only on the segment of the value chain in which they are superior than the competitors. McIvor, Humphreys, and McAleer (1997) implemented conceptual framework for evaluating make or buy decisions based on criteria of core competencies, internal versus external capability and cost. The author illustrated that make or buy is a strategic decision and has implications for the overall corporate strategy of the organization by describing a model that involved analyzing a number of strategic factors. Companies have been moving significantly away from "making" towards "buying". However, research has revealed that make or buy decisions are rarely taken within a thoroughly strategic perspective. Many firms adopt a short-term perspective and are motivated primarily by the search for short-term cost reductions. It is argued that make or buy decisions are made most frequently by default with little consideration for the long-run competitiveness of the organization. The make or buy model described by McIvor attempted to overcome these problems by offering an organization a conceptual framework to follow in the sourcing decision. The model presented an outline of three key problems encountered by companies in their efforts to formulate an effective make or buy decision to illustrate the weaknesses in current make or buy practice.

However, these strategic models of above-mentioned literatures were generally built in the traditional cost and strategic point of view. According to industrialists interviews, it was therefore difficult to apply the above-mentioned models to solve the practical problems of make or buy in practical Japanese automobile manufacturing companies.

This paper, therefore, aims at proposing an empirical model of make or buy decision applied to Japanese automobile manufacturing plants from both the theoretical and practical points of views. The research methodology in this paper is shown in Figure 1 as follows:

- First, a theoretical method was studied from a literature review.

- Second, the data (main criteria and sub-criteria) for deciding a make or buy was assessed from interviewing industrialists from a practical point of view. In this research, six companies in the automobile industry ranging from medium to large sizes were chosen for interviewing and collecting data.

- Third, a model of make or buy was proposed based on theoretical and practical point of views from Japanese automobile industry.

- Fourth, the proposed model was reconfirmed with the industrialists.

- Fifth, the proposed decision making method was applied in an actual make or buy project in company $A$ to check against the validation of the model. 


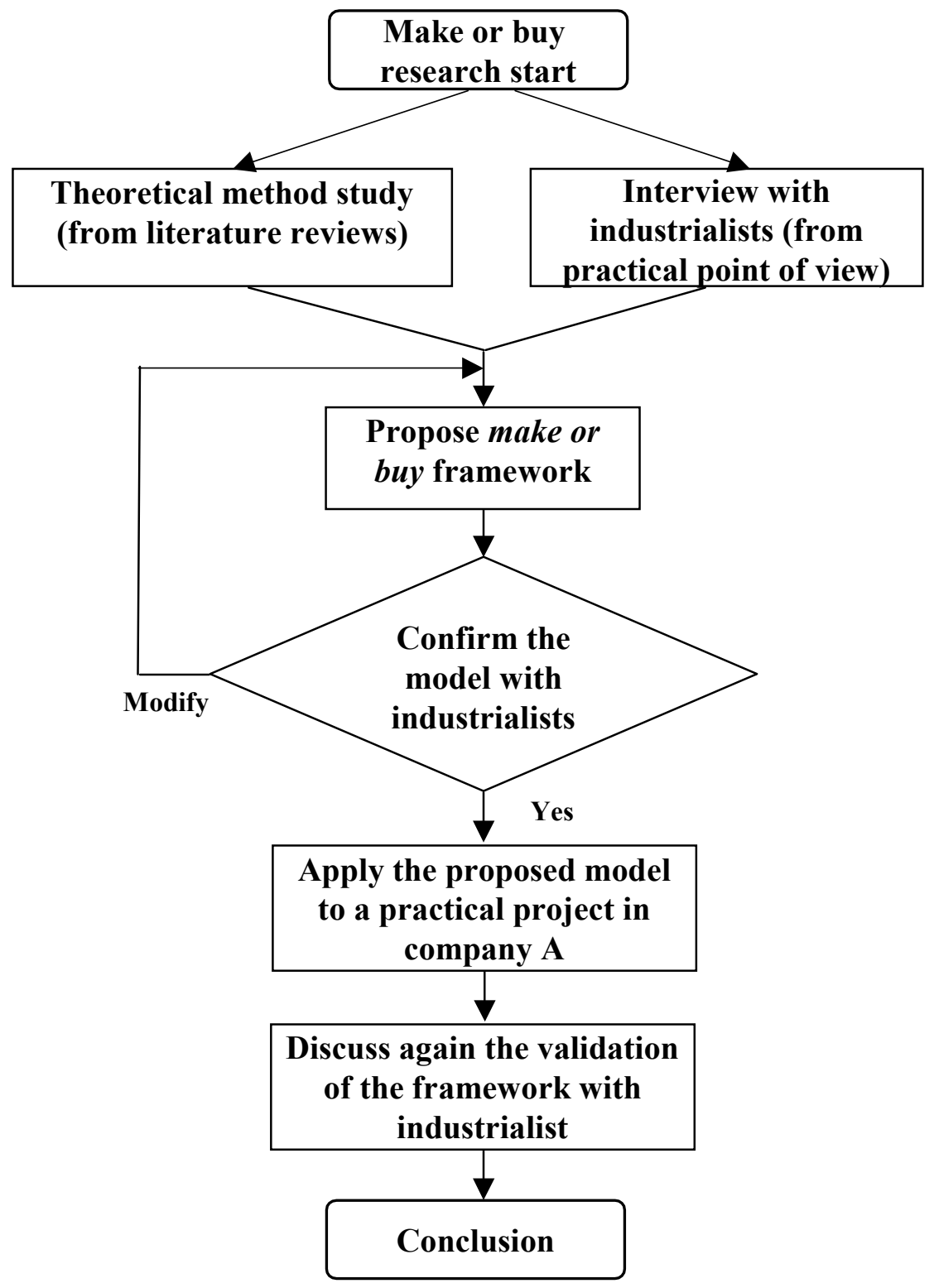

Figure 1: Research methodology

\section{ANALYTIC HIERARCHY PROCESS METHOD}

The AHP method (Saaty 1988, 1990, 1992, and 2006; Saaty and Tran 2007) has been chosen for developing a hierarchical make or buy model in this research. Other methods of multiple criteria decision making may be viable for this purpose but were not chosen for several reasons:

- The AHP method allows for all factors of the decision problem to be considered and related in logical structure.

- The AHP method does not require the decision maker to specify quantitative ranking of weights for variables directly as other method such as scoring methods where decision maker assesses values and provides numerical weights. AHP allows the decision to be made in more detail.

- AHP can be used and understood easily by decision makers, and it is also very flexible.

- There are three steps involved in the use of the AHP model as described below in Figure 2: 
1. Problem decomposition: The general objective of the make or buy (level 1 ) is decomposed and arranged in a hierarchy of main criteria (level 2) and each main criteria is further decomposed into sub-criteria (level 3) ...etc. The decomposing process is done until the lowest of the hierarchy is reached (level $k+2)$.

2. Comparative analysis: The relative importance of each main criteria and sub-criteria at a particular level are measured by the procedure of pairwise comparison. The decision makers provide numerical values for the priority of each criterion using a rating scale. The relative importance of each factor is rated by a measurement scale that decision maker provides with numerical judgments corresponding to verbal judgments. The instrument used is often a discrete scale, from 1 to 9 with one representing the equal importance of two factors and nine being the highest possible importance of one factor over another.

3. Synthesis of priority: The priority weights at each level are computed using an eigenvector or least square analysis method. The process is repeated for each level of the hierarchy until a decision is finally reached by overall composite weights.

\section{Level 1: Overall objective (Make or Buy from Supplier Ai)}

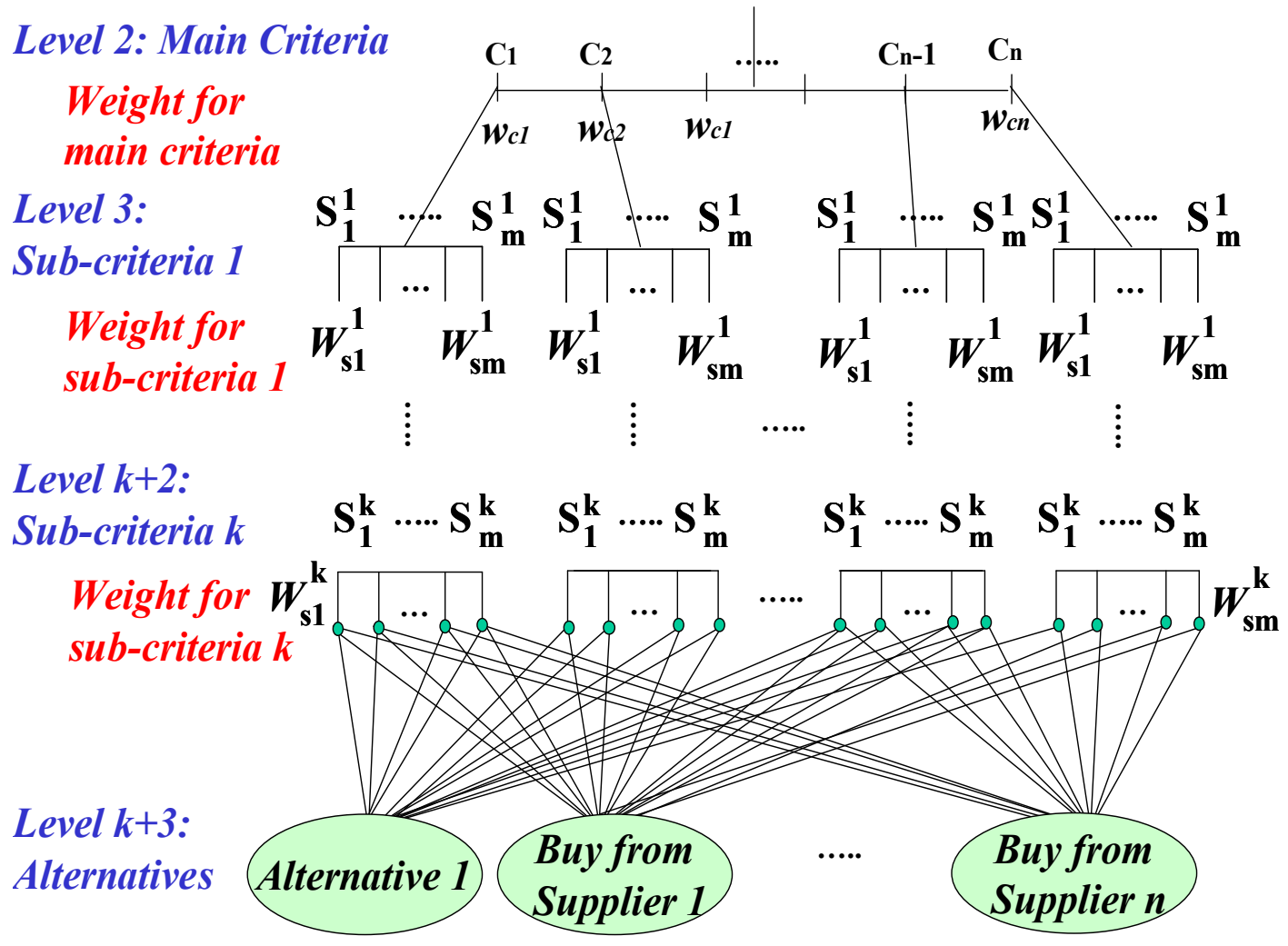

Figure 2: AHP construction for make or buy

\section{INTERVIEWS WITH INDUSTRIALISTS}

The aim of the interviews was to find out a comprehensive practical point of view of companies for make or buy issues. Managers heading different departments including purchasing, domestic and overseas factory, $\mathrm{R} \& \mathrm{D}$, production engineering, quality-control, marketing, finance and accounting in six Japanese auto companies from middle to large size were interviewed (Table 1). 
Minh

Table 1: Interviewed companies

\begin{tabular}{|l|l|}
\hline Company & Sector \\
\hline A & Car manufacturer \\
\hline B & Vehicle Electronic instrument \\
\hline D & Car component, jig, die \\
\hline C & Car component \\
\hline E & Jig, die, car component \\
\hline G & Instrumentation, car component \\
\hline
\end{tabular}

The interview with each person was for about 50 minutes and included the following issues: core business, quality, manufacturing process and technology, finance (equipment investment, manufacturing cost, supplier transaction cost), supply chain management and logistic system, main criteria and subcriteria for make or buy decision. The interviews notes were then analyzed to find the main issues of interest. The interview results showed that the make or buy process in each company was investigated by a project team through many discussions with related divisions within the company.

\subsection{Main Criteria}

Main criteria were found from practical point of view of the interviewed industrialists. The following five practical strategies were used as main criteria for make or buy decision making process:

- $\quad$ Product strategy

- Quality strategy

- Cost and finance strategy

- Manufacturing technology strategy

- Supply chain management and logistics strategy

The priority of above-mentioned criteria are based on agreement of make or buy investigation team with managers of all related divisions of the company. For each concrete project, the project team investigates the individual characteristics and summarizes the result of each main criteria priority. For example, the product strategy would be considered as first priority for project $P 1$ but this could be considered as fifth priority for other project $P 2$.

\subsection{Sub Criteria}

Sub-criteria for each of the main criteria were also discussed with interviewed managers and the final results were summarized in Table 2. Note that the priority of each sub-criterion also depends on every concrete project. Similar to the main criteria, priory of sub-criteria were decided based on agreement of project team within the related divisions of the company

\subsection{Alternatives}

According to the interviewed industrialists, the number of suppliers depended on each concrete project. Due to project lead-time limitations, normally a maximum of two suppliers from the database of the company were taken into account in the investigation of the make or buy decision-making process. As a result, three alternatives of make or buy investigation were considered for the study in Figure 3. 
Minh

Table 2: Sub-criteria for a make or buy project

\begin{tabular}{|c|c|}
\hline Main criteria & Sub-criteria \\
\hline \multirow[t]{3}{*}{ Product strategy } & Core business \\
\hline & Market expects the company to make the product \\
\hline & Threat from future competition \\
\hline \multirow[t]{3}{*}{ Quality strategy } & Quality insurance \\
\hline & Quality level (number of defect, scrap) \\
\hline & Quality management \\
\hline \multirow{3}{*}{$\begin{array}{c}\text { Cost and finance } \\
\text { strategy }\end{array}$} & Cost competitive (in-house and transaction cost) \\
\hline & Company finance availability \\
\hline & Cost reduction activities \\
\hline \multirow{3}{*}{$\begin{array}{c}\text { Manufacturing } \\
\text { technology } \\
\text { strategy }\end{array}$} & Proprietary company manufacturing know-how \\
\hline & Manufacturing technology level \\
\hline & Enough capacity for manufacturing \\
\hline \multirow{3}{*}{$\begin{array}{l}\text { Supply chain } \\
\text { management \& } \\
\text { logistics strategy }\end{array}$} & Stable supply \\
\hline & Flexible for product demand fluctuation \\
\hline & Efficient logistics and on time delivery \\
\hline
\end{tabular}

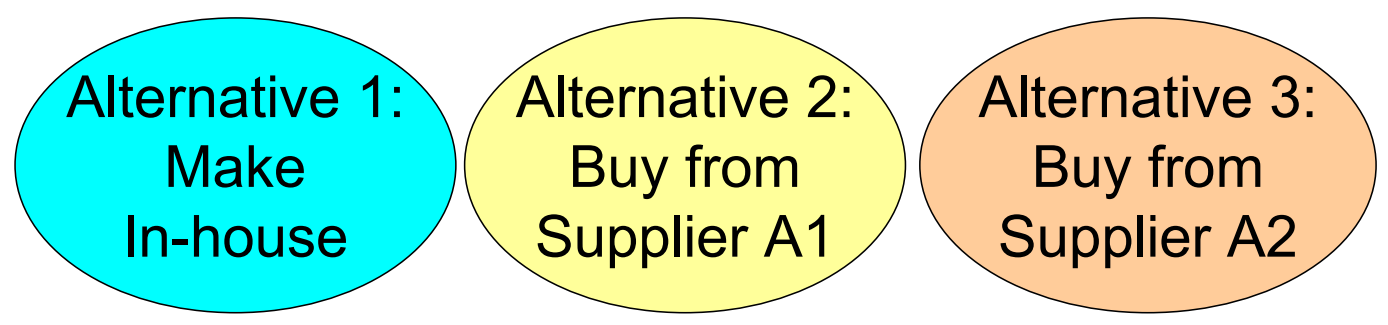

Figure 3: Alternatives for make or buy analysis

\section{THE PROPOSED MAKE OR BUY MODEL}

The AHP model for the make or buy process was proposed by utilizing both theoretical and practical point of views. The main criteria, sub-criteria and alternatives of the make or buy decision making process were constructed following the analysis results from the interviews. As shown in Figure 4, the model was composed of a four level hierarchy given as:

- Level 1: General objective of making in-house or buying from a capable supplier

- Level 2: Main criteria

- Level 3: Sub-criteria

- Level 4: Alternatives

The proposed AHP model was also confirmed again with industrialists, with most of them agreeing with the model. 


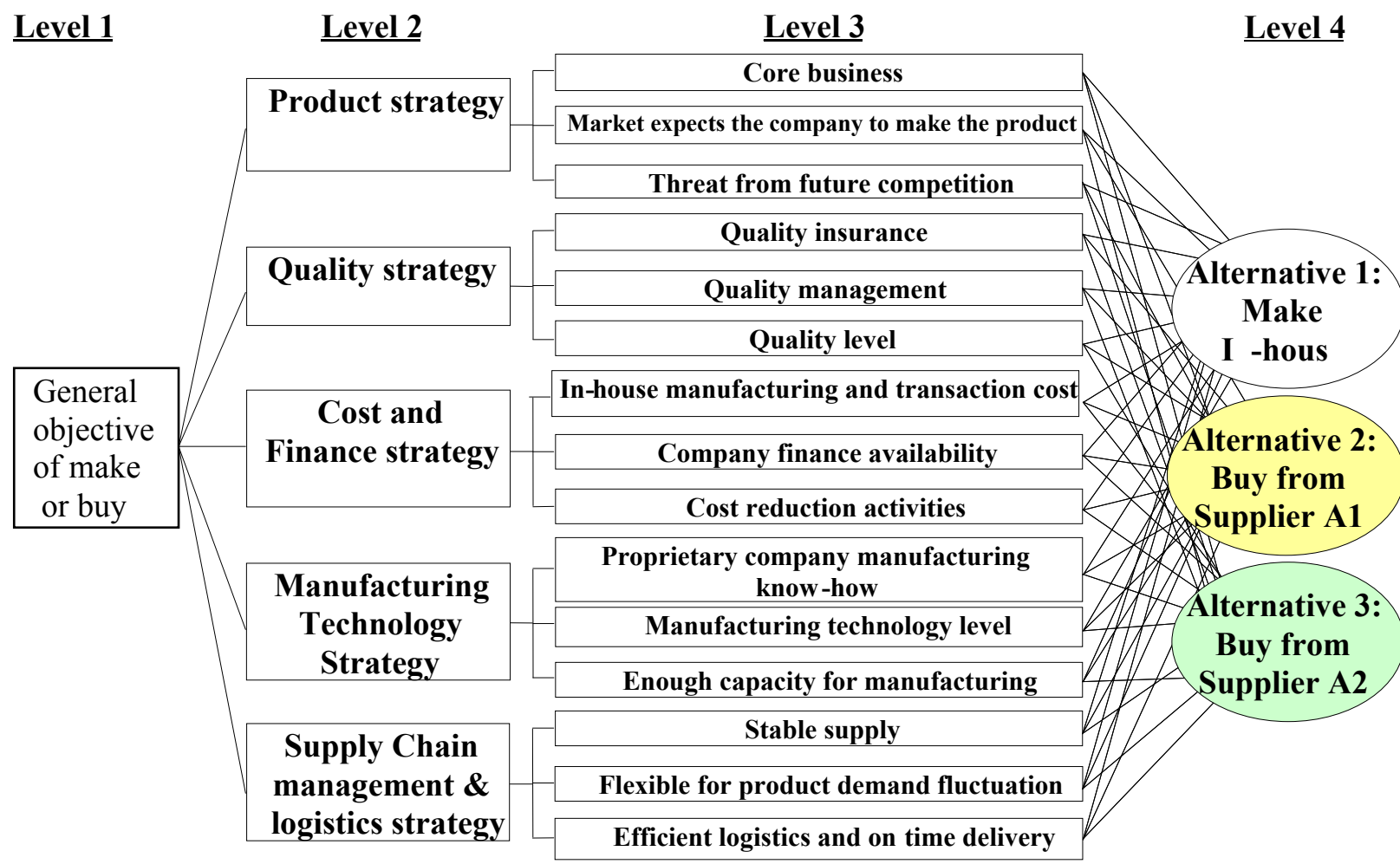

Figure 4: The proposed AHP model for make or buy decision making process

The scale of rating for a pairwise comparison also was discussed. Decision makers from all interviewed companies also agreed on using a discrete 9-point scale measure (1 to 9 for collecting data of every level of the AHP model).

Based on the proposed model, the make or buy investigation team will organize discussions with the related divisions to collect data for a pairwise comparison including data of a pairwise comparison of the main criteria with respect to a general objective, sub-criteria with respect to the main criteria and alternatives with respect to the sub-criteria. The weight of each level will be calculated based on the AHP method.

\section{APPLICATION OF THE PROPOSED MODEL TO AN ACTUAL PROJECT}

An actual project in the making of a crucial component part for a vehicle of company A was introduced for further understanding of the proposed model. The project team investigated the make or buy process of the project as follows:

- The team studied the project information given by the top class manager of the company such as, manufacturing line capacity, product model life, process cycle time, and product drawings.

- Based on the product information, the project team conducted sufficient discussions with the related divisions and suppliers for the purpose of collecting data for the proposed AHP model.

\subsection{Data for Main Criteria}

The priority of every main criteria are given as: Product strategy $(P)>$ Quality strategy $(Q)>$ Cost and Finance strategy $(C)>$ Manufacturing technology strategy $(M)>$ Supply chain management strategy $(S)$. For example, the data for comparing the relative importance (pairwise comparison) of the main criteria with respect to overall objective summarized in Table 3 shows that the priority of product strategy is 1.5 , 
2.0, 3.0, 6.0 greater than quality strategy, cost and finance strategy, manufacturing technology, and supply chain management strategy respectively.

Table 3: Pairwise comparison of the main criteria with respect to the overall objective

\begin{tabular}{|l|l|l|l|l|l|}
\hline & $\mathrm{P}$ & $\mathrm{Q}$ & $\mathrm{C}$ & $\mathrm{M}$ & $\mathrm{S}$ \\
\hline $\mathrm{P}$ & 1.0 & 1.5 & 2.0 & 3.0 & 6.0 \\
\hline $\mathrm{Q}$ & $1 / 1.5$ & 1.0 & 2.0 & 2.5 & 5.0 \\
\hline $\mathrm{C}$ & $1 / 2.0$ & $1 / 2.0$ & 1.0 & 1.5 & 3.0 \\
\hline $\mathrm{M}$ & $1 / 3.0$ & $1 / 2.5$ & $1 / 3.0$ & 1.0 & 2.0 \\
\hline $\mathrm{S}$ & $1 / 6.0$ & $1 / 5.0$ & $1 / 3.0$ & $1 / 2.0$ & 1.0 \\
\hline
\end{tabular}

\subsection{Data of sub-criteria}

The priorities and actual pairwise comparison rate of sub-criteria are given below:

- Product strategy:

As shown in Table 4, the priority of sub-criteria with respect to product strategy is quoted as: Core business $(\mathrm{cb})>$ Market expect the company make the product $(\mathrm{me})>$ Threat from the future competition (fc).

Table 4: Pairwise comparison of the sub-criteria with respect to product strategy

\begin{tabular}{|l|l|l|l|}
\hline & $C b$ & $m e$ & $f_{c}$ \\
\hline$c b$ & 1 & 3 & 6 \\
\hline$m e$ & $1 / 3$ & 1 & 2 \\
\hline$f_{c}$ & $1 / 6$ & $1 / 2$ & 1 \\
\hline
\end{tabular}

\section{- Quality strategy:}

The data of the pairwise comparison sub-criteria with respect to quality strategy are illustrated in Table 5: Quality insurance (qi) > Quality level (ql) > Quality management (qm).

Table 5: Pairwise comparison of the sub-criteria with respect to quality strategy

\begin{tabular}{|l|l|l|l|}
\hline & $q i$ & $q l$ & $Q m$ \\
\hline$q i$ & 1 & 2 & 4 \\
\hline$q l$ & $1 / 2$ & 1 & 2 \\
\hline$q m$ & $1 / 4$ & $1 / 2$ & 1 \\
\hline
\end{tabular}

- Cost and finance strategy:

Table 6 describes the pairwise comparison of these sub-criteria with respect to cost and finance strategy: Cost competitiveness (cc) $>$ Cost reduction activities $(c d)>$ Company finance availability $(f a)$. 
Table 6: Pairwise comparison of the sub-criteria with respect to cost and finance strategy

\begin{tabular}{|l|l|l|l|}
\hline & $c c$ & $c d$ & $f a$ \\
\hline$c c$ & 1 & 2.5 & 5 \\
\hline$c d$ & $1 / 2.5$ & 1 & 2 \\
\hline$f a$ & $1 / 5$ & $1 / 2$ & 1 \\
\hline
\end{tabular}

\section{- Manufacturing technology strategy:}

The data of pairwise comparison of sub-criteria with respect to manufacturing technology strategy is given in Table 7: Proprietary manufacturing know-how of the company (rm) > Manufacturing level $(\mathrm{ml})>$ Enough capacity for manufacturing (ec).

Table 7 - Pairwise comparison of the sub-criteria with respect to Manufacturing technology strategy.

\begin{tabular}{|l|l|l|l|}
\hline & $r m$ & $m l$ & $e c$ \\
\hline$r m$ & 1 & 1.5 & 3 \\
\hline$m l$ & $1 / 1.5$ & 1 & 2 \\
\hline$e c$ & $1 / 3$ & $1 / 2$ & 1 \\
\hline
\end{tabular}

\section{- Supply chain management strategy:}

Table 8 illustrates the data of the pairwise comparison of these sub-criteria with respect to supply chain management strategy: Stable supply (ss) > Flexible for product demand fluctuation (fd) > Efficient logistic system (el).

Table 8: Pairwise comparison of the sub-criteria with respect to Supply chain management and logistic strategy

\begin{tabular}{|l|l|l|l|}
\hline & $s t$ & $f d$ & $e l$ \\
\hline$s t$ & 1 & 3 & 6 \\
\hline$f d$ & $1 / 5$ & 1 & 2 \\
\hline$e l$ & $1 / 4$ & $1 / 2$ & 1 \\
\hline
\end{tabular}

\subsection{Data for Alternatives}

Data for the Alternatives

The data for a pairwise comparison of alternatives with respect to the sub-criteria were also summarized, and examples of the pairwise comparison of alternatives with respect to sub-criteria (core business, market expects the company make the product, threat from future competition) are given in Table 9.

\section{ANALYSIS RESULTS}

Expert Choice software (Expert choice, Inc. 2011) was used in calculating the weight value of each level of the model (main criteria, sub-criteria, alternative). 
Table 9: Image of pairwise comparison of the alternatives with respect to sub-criteria

\begin{tabular}{|c|c|c|c|c|c|}
\hline $\begin{array}{c}\text { Main } \\
\text { criteria }\end{array}$ & Sub-criteria & & $\begin{array}{l}\text { g scor } \\
\text { ecisior }\end{array}$ & $\begin{array}{l}\text { assess } \\
\text { nakers }\end{array}$ & \\
\hline \multirow{11}{*}{$\begin{array}{l}\text { Product } \\
\text { strategy }\end{array}$} & \multirow{4}{*}{ Core business } & & M.I.H & B.F.A1 & B.F.A2 \\
\hline & & M.I.H & 1 & 2 & 4 \\
\hline & & B.F.A1 & $1 / 2$ & 1 & 2 \\
\hline & & B.F.A2 & $1 / 4$ & $1 / 2$ & 1 \\
\hline & \multirow{4}{*}{$\begin{array}{c}\text { Market expect the } \\
\text { company make the } \\
\text { product }\end{array}$} & & & & \\
\hline & & M.I.H & 1 & 3 & 5 \\
\hline & & B.F.A1 & $1 / 3$ & 1 & 2 \\
\hline & & B.F.A2 & $1 / 5$ & $1 / 2$ & 1 \\
\hline & \multirow{3}{*}{$\begin{array}{l}\text { Threat from future } \\
\text { competition }\end{array}$} & M.I.H & 1 & 1 & 1 \\
\hline & & B.F.A1 & 1 & 1 & 1 \\
\hline & & B.F.A2 & 1 & 1 & 1 \\
\hline
\end{tabular}

Note: M.I.H=make in house; B.F.A1= buy from supplier 1; B.F.A2 = buy from supplier 2

The final result of priority for each alternative is described in Figure 5. The final result shows that alternative 1 (make in-house) had the highest weight value (0.519). As result, the final decision of the project was to make in-house.

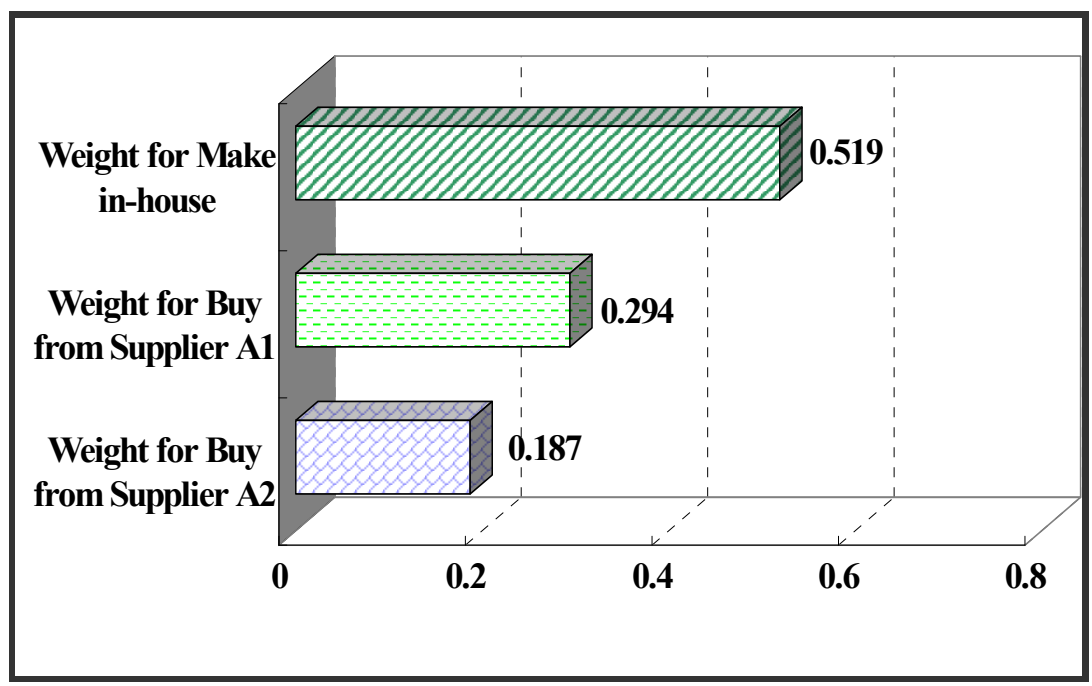

Figure 5: Final priority of the project

The results of the study were discussed again with the industrialists. The results completely agreed with the results from conventional method that for the most part were based only on experience. The proposed AHP was very useful for persuading a manager for approving the final decision. Furthermore, the industrialists also commented that the data collection process for pairwise comparison of main-criteria and sub-criteria represented a positive process in identifying the characteristics of the project. Therefore, 
the data can be used as evidence in persuading joint-discussion members and division managers within a company. The model could be used widely in investigating make or buy decisions for upcoming projects in the company.

\section{CONCLUSIONS}

This paper has contributed to both the theory and implementation of the make-or-buy decision in Japanese automobile manufacturing plants. The model was built from a new perspective with main criteria and sub-criteria of make-or-buy decision-making model captured from interviews with Japanese automobile manufacturers.

The interviewed managers also highly appreciated the practical application of the model. The proposed AHP model can not only be used for automobile companies, but the idea of this model could be extended to other industries as well.

\section{REFERENCES}

Balakrishnan, S. 1994. “The Dynamics of Make-or-Buy Decisions.” European Journal of Operational Research 74:552-571.

Buchowicz, B. S. 1991. "A Process Model of Make-or-Buy Decision-Making: The Case of Manufacturing Software." IEEE Transactions on Engineering Management 38:24-32.

Coase, R. H. 1937. "The Nature of the Firm." Economica N. S. 4:386-405.

David, R. J., and K. H. Shin. 2004. "A Systematic Assessment of the Empirical Support for Transaction Cost Economics." Strategic Management Journal 25:39-58.

Expert choice, Inc. 2011. "Expert Choice.” Accessed July 23. http://www.expertchoice.com/productsservices/expert-choice-desktop/.

Jennings, D. 1997. "Strategic Guidelines for Outsourcing Decision.” Strategic Change 6:85-96.

Langlois, R. N., and L. R. Paul. 1989. "Explaining Vertical Integration: Lessons from the American Automobile Industry." Journal of Economic History 49:361-375.

Masten, S. E., W. M. James, and A. S. Edward. 1989. "Vertical Integration in the U.S. Auto Industry: A Note on the Influence of Specific Assets." Journal of Economic Behavior and Organization 12:26573.

Masters, J., and M. Grant. 2002. "Predicting the Use of External Labor Arrangements: A Test of the Transaction Cost Perspective." Academy of Management Journal 45:431-442.

McIvor, R. T., P. K. Humphreys, and W. E. McAleer. 1997. "A Strategic Model for the Formulation of an Effective Make-or-Buy Decision." Management Decision 32(2):169-78.

Mike, T., and D. Colin. 2001. "Moving from Make-Buy to Strategic Sourcing: The Outsource Decision Process." Long Range Planning 34:605-622.

Probert, D. R. 1997. Developing a Make-or-buy Strategy for Manufacturing Business. London, UK: The Institution of Electrical Engineers.

Porter, M. E. 1985. Competitive Advantage. New York: Free Press.

Quinn, J. B., and F. G. Hilner. 1995. "Strategic Outsourcing." McKinsey Quarterly 1:43-55.

Ohanian, N. K. 1994. "Vertical Integration in the U.S. Pulp and Paper Industry, 1900-1940." Economics and Statistics 74:202-207.

Rindfleisch, A., and J. B. Heide. 1997. "Transaction Cost Analysis: Past, Present, and Future Applications." Journal of Marketing 61:30-54.

Saaty, T. L. 1988. Decision Making for Leaders. Pittsburgh, PA: RWS Publications.

Saaty, T. L. 1990. "Physics as a Decision Theory." European Journal of Operational Research 48:98104.

Saaty, T. L. 1992. Multi-criteria Decision Making - The Analytic Hierarchy Process. Pittsburgh, PA: RWS Publications. 
Saaty, T. L. 2006. "Decision Aiding Rank from Comparisons and from Ratings in the Analytic Hierarchy/Network Processes." European Journal of Operational Research 168:557-570.

Saaty, T. L., and L. T. Tran. 2007. "On the Invalidity of Fuzzifying Numerical Judgments in the Analytic Hierarchy Process." Science Direct Mathematical and Computer Modeling 46:962-975.

Vannoni, D. 2002. "Empirical Studies of Vertical Integration: The Transaction Cost Orthodoxy." International Review of Economics and Business 49:113-41.

Venkatesan, R. 1992. "Strategic Sourcing: To Make or Not to Make." Harvard Business Review 70(6):98-107.

Welch, J.A., and P. R. Nayak. 1992. "Strategic Sourcing: A Progressive Approach to the Make-or-Buy Decision." Academy of Management Executive 6(1):23-31.

Williamson, O. E. 2005. "Transaction Cost Economics and Business Administration." Scandinavian Journal of Management 2:19-40.

\section{AUTHOR BIOGRAPHIES}

NGUYEN DANG MINH is a lecturer in the Graduate School of Business at University of Economics and Business, Vietnam National University, Hanoi. He is also a researcher of Viet Nam Development Forum (VDF). Before moving to academia, he had 7 years of working experience in production engineering field at the headquarter of Toyota Motor Corporation, Japan. He received his M.Sc. degree in Mechanical Engineering at The University of Tokyo, and Ph.D. degree in Business Administration at Nagoya University, Japan. His research interests are in the area of optimization of make or buy decision making process, production line design using simulation and multiple economic factors. His research interest also includes application of Toyota Production System in non-Japanese companies, and out-source purchasing of manufacturing firm. His email address is nguyendangminh@hotmail.com. 